\title{
Survey and Testing at the Proposed Dos Rios Wastewater Treatment Plant, South Bexar County, Texas. San Antonio 201 Wastewater Treatment Project
}

Michael C. Woerner

Follow this and additional works at: https://scholarworks.sfasu.edu/ita

Part of the American Material Culture Commons, Archaeological Anthropology Commons, Environmental Studies Commons, Other American Studies Commons, Other Arts and Humanities Commons, Other History of Art, Architecture, and Archaeology Commons, and the United States History Commons

Tell us how this article helped you.

This Article is brought to you for free and open access by the Center for Regional Heritage Research at SFA ScholarWorks. It has been accepted for inclusion in Index of Texas Archaeology: Open Access Gray Literature from the Lone Star State by an authorized editor of SFA ScholarWorks. For more information, please contact cdsscholarworks@sfasu.edu. 
Survey and Testing at the Proposed Dos Rios Wastewater Treatment Plant, South Bexar County, Texas. San Antonio 201 Wastewater Treatment Project

\section{Creative Commons License}

\section{(c) (i) (8)}

This work is licensed under a Creative Commons Attribution-NonCommercial 4.0 International License 


\section{SURVEY AND TESTING AT THE PROPOSED \\ DOS RIOS WASTEWATER TREATMENT PLANT, SOUTH BEXAR COUNTY, TEXAS}

San Antonio 201 Wastewater Treatment Project

Mi chael C. Woerner

Center for Archaeological Research The University of Texas at San Antonio Archaeological Survey Report, No. 122 



\section{ABSTRACT}

In June 1982; the Center for Archaeological Research, The University of Texas at San Antonio (CAR-UTSA), conducted an archaeological survey with subsurface testing at the proposed Dos Rios Wastewater Treatment Plant (previously called the Confluence site) located in Bexar County, Texas. The survey was performed for the City of San Antonio and was conducted under the administration of a joint venture of consulting engineers, acting as the city's representatives. Two archaeological sites (41 BX 124 and 41 BX 567) were examined. No further work is recommended for 41 BX 124 . However, 41 BX 567 needs further investigation to determine eligibility for nomination to the National Register of Historic Places. 
TABLE OF CONTENTS

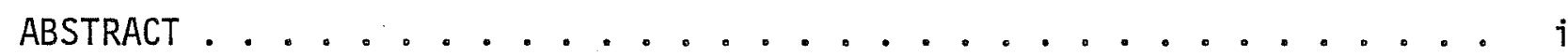

LIST OF FIGURES ......................... $i$

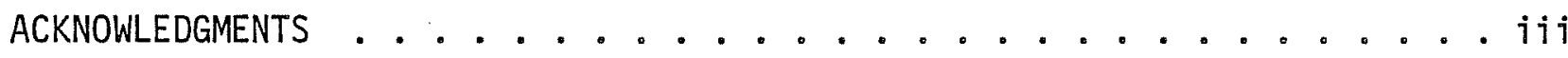

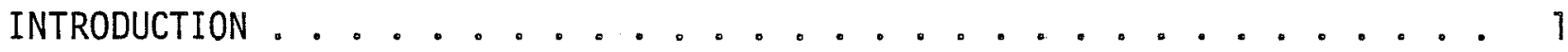

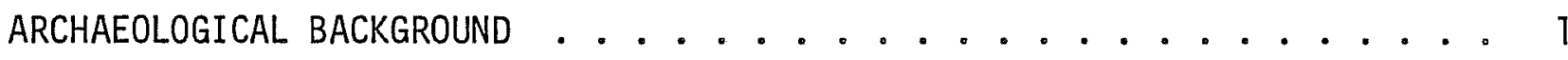

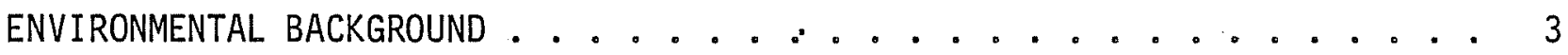

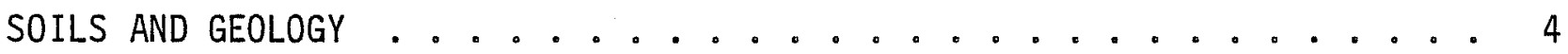

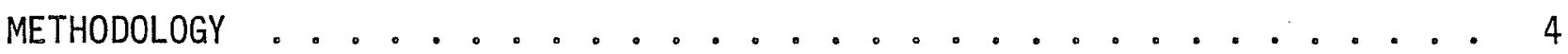

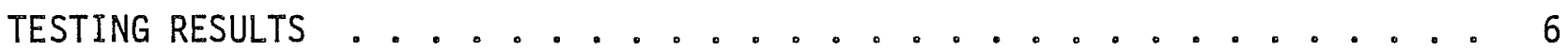

SUMMARY AND RECOMMENDATIONS ........................ 10

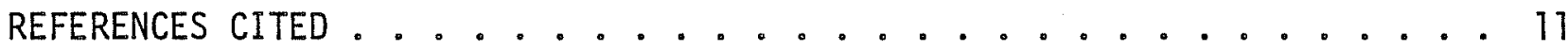

\section{LIST OF FIGURES}

1. Location of Project Area ................ 2

2. Map of Survey Area ................. 5

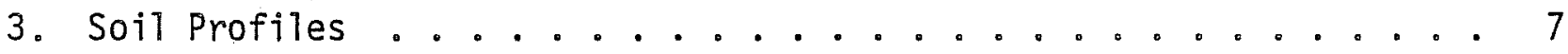

4. Map of 41 BX $567 \ldots \ldots \ldots$ 


\section{ACKNOWLEDGMENTS}

There are many people to thank for aid in accomplishing this phase of the San Antonio 201 Wastewater Treatment Project. Dr. Edward Galwardi, Mr. Salah Diab, Mrs. Mary Bell Haney, and Mr. Jim Overby, all of Joint Venture, were very helpful in providing maps and information essential for the field work. Augustine Frkuska and Daniel Potter shared the field work with the author. The preparation of this report was also aided by the help of Jack Eaton, Sharon Quirk, and Mary Lou Ellis. 



\section{INTRODUCTION}

The Center for Archaeological Research (CAR), The University of Texas at San Antonio (UTSA), is under contract with the City of San Antonio to provide evaluations and recommendations for the management of cultural resources for the San Antonio 201 Wastewater Facilities Improvements Program. This report supplies an archaeological assessment of recently acquired land at the proposed Dos Rios Wastewater Treatment Plant in south Bexar County, Texas. The assessment was done at the request and through the administration of Pape-Dawson, Inc., Vickrey and Associates, Inc., and Lockwood, Andrews and Newnam, Inc., a joint venture of consulting engineers designated as the city's representatives.

The archaeological field studies and analysis comply with the Texas Antiquities Code, the National Historic Preservation Act of 1966, the National Environmental Policy Act of 1969 (NEPA), and Executive Order 11593 as part of the planning process required for the construction of federally funded wastewater works under Section 201, Federal Water Pollution Control Act Amendments of 1972 (PL 92-500). The project in which the archaeological investigations are involved was funded in part by grants from the United States Environmental Protection Agency.

The survey area consists of approximately 525 acres at the confluence of the San Antonio and Medina Rivers (Fig. 1). The field work was conducted during June 21-25, 1982, by CAR staff archaeologists, Augustine Frkuska, Jr., Michae1 Woerner, and Daniel Potter. Overall supervision was provided by Dr. Thomas R. Hester (Director) and Jack Eaton (Associate Director) of the CAR. At the completion of the field work, a preliminary report was submitted to consulting engineers describing field work accomplished and providing basic recommendations (Woerner 1982).

\section{ARCHAEOLOGICAL BACKGROUND}

In recent years extensive archaeological work has been done in San Antonio and the surrounding Bexar County area, resulting in over 500 documented archaeological sites. The examination of most sites, unfortunately, has been limited to surface survey. Intensive surveys conducted in Bexar County include an examination of flood control dams on the tributaries of the Salado Creek (Hester et al. 1974) and a cultural resource assessment of Fort Sam Houston and its south-central Texas properties (Gerstle, Kelly, and Assad 1978). The CAR has also been responsible for the excavations of numerous historic and prehistoric sites in Bexar County. Fawcett (1972), Hester (1980), and Black and McGraw (1982) provide information on the archaeology of south-central Texas.

The initial archaeological assessment of the Ashley property, where the Dos Rios Plant site is to be located, was made in 1977 by D. Brown, a CAR archaeologist (Fox 1977). Site 41 BX 124 was recorded at this time. An examination of artifacts collected from the site by the owner, Marvin Ashley, suggested an occupational history from the Archaic period (6000 B.C.-A.D. 1000) to the Late Prehistoric period (ca. A.D. 1000-1600). In order to determine depth, extent, and the possible significance of 41 BX 124, additional surveying and subsurface testing were recommended (Fox 1977). 
This page has been

redacted because it

contains restricted

information. 
In 1978, an intensive survey and limited subsurface testing of 41 BX 124 and the immediate area were conducted. The most dense concentration of lithic material occurred in a heavily disturbed area in the southeast portion of the site. Two test units $\left(50 \mathrm{~cm}^{2}\right)$ were excavated in the area to a maximum depth of $40 \mathrm{~cm}$. One unit was placed within a pig pen where most of the owner's collection came from. The other unit was located outside of the pen to the south. No diagnostic artifacts or substantial lithic materials were recovered from these tests; however, it was evident that there was a prehistoric site in this location, now almost totally deflated. Additional artifacts collected from the site by $\mathrm{Mr}$. Ashley prior to the CAR excavations in 1978 included Guadalupe tools, which indicate a potential Pre-Archaic (ca. 6000-3500 B.C.) occupation. Backhoe trenching, to test for undisturbed deposits in the northern and eastern margins of the site, was recommended at that time (Fox, McGraw, and Valdez 1978). Another prehistoric site that is outside the study area, but adjacent to it, is $41 \mathrm{BX} 226$. Known as the Bly site, it is located on the high terraces of the Medina River opposite the survey area (Fig. 1). The site was recorded in 1977 by $A$. Fox at the invitation of the owner, Earl Bly (notes on file, CAR).

\section{ENVIRONMENTAL BACKGROUND}

The climate of Bexar County is "modified subtropical" with mild winters and hot summers. Temperature extremes range from $0^{\circ} \mathrm{F}$ to $107^{\circ} \mathrm{F}$ with a mean annual temperature of $70^{\circ} \mathrm{F}$. Precipitation is relatively constant throughout the year, averaging between 25 inches to 30 inches annually (Taylor, Hailey, and Richmond 1966).

The vegetation of the survey area is limited to cultivated crops, with short scrub brush, mesquite, and large pecan trees along the San Antonio and Medina Rivers. Blair (1950) includes the area in the Tamaulipan Biotic Province.

Modern climatic and vegetational conditions are not reflective of paleoenvironmental patterns. During the Late Pleistocene the environment was cooler and moister than now, with grassland savannahs in many areas. Analys is of pollen and phytoliths from south Texas sediments indicates increased aridity beginning around 8000 B.C. (Robinson n.d.). The explosive growth of dense mesquite thickets common in south Texas is a relatively recent phenomenon triggered during the 19th century by overgrazing, short-term climatic changes, and the suppression of brush fires (Hester 1980).

Bexar County is divided from west to northeast by the Balcones Fault Zone. North of the zone is the Edwards Plateau, and to the south and east are the Blackland Prairies, a subdivision of the Gulf Coastal Plains Physiographic Region. The central portion of the Edwards Plateau is characterized by undulating to slightly rolling areas with deep soils. In the vicinity of the Balcones Fault Zone, the plateau is deeply dissected by numerous small drainages, resulting in a rugged hilly topography with severely eroded surfaces. The Blackland Prairies are characterized by wide shallow lowland valleys with deep alluvial deposits (Johnson 1931; Anonymous 1981). 
The survey area is located at the confluence of the Medina and San Antonio Rivers. Although the average annual discharge of the river is smal1 $(350,000$ acre-feet), its own natural springs, in combination with those of its major tributaries, the Medina River and Cibolo Creek, contribute to a year-round flowing river.

\section{SOILS AND GEOLOGY}

The topography of the project area is flat to gently rolling with 100 feet of vertical relief. The highest elevation is 512 feet above mean sea level in the northeast corner of the survey area; the lowest elevation is 405 feet at the confluence. Steep embankments and near vertical bluffs are present along both the Medina and San Antonio Rivers.

The surface soils of the area belong largely to the Venus-Frio-Trinity Association, which are deep, calcareous soils on bottom lands and terraces. $A$ small portion of the soils belong to the San Antonio Crockett Association, which are deep clay loams and sandy loams with claypan (Anonymous 1981; Taylor, Hailey, and Richmond 1966).

\section{METHODOLOGY}

The project began with an overal1 surface examination of the site. Areas to be heavily impacted were closely examined, and selected areas were designated for backhoe trenching. Known archaeological sites and areas of high site probability, particularly terraces and drainages, were also studied. Archaeological sites were recorded on standard CAR site survey forms and are on file at the CAR and the Texas Archeological Research Laboratory in Austin. Collected artifacts were returned to the CAR for analysis and curation.

Subsurface testing included 45 separate backhoe excavations in the survey area. These were placed in areas of planned greatest impact as indicated on engineering drawings, and also in areas where site potential was highest, mostly on old river terraces. Using a transit and stadia rod, five basel ines were established through selected areas, and trenches were spaced along the baseline intervals (Fig. 2). Each backhoe excavation was assigned an alphanumeric provenience label. Each trench series was designated by a letter $(A, B, C$, etc.), while the numerical coefficient represents the individual trench within that series.

The excavation of each trench was monitored by an archaeologist. As excavation was completed, each trench profile was cleaned and examined for cultural deposits. The profile was recorded for soil color, consistency, and composition. Al1 trenches were backfilled after recording.

A previously recorded site, 41 BX 124, was re-examined and a surface collection was made. Two backhoe trenches were excavated within the estimated limits of the site. A previously unknown site, $41 \mathrm{BX} 567$, was recorded during the current project. The site was carefully examined, and surface artifacts were 
This page has been

redacted because it

contains restricted

information. 
collected. Subsurface testing included a shovel test and two backhoe trenches. The shovel test was placed in the northern area of the site where potential for cultural materials appeared to be best. The backhoe trenches were placed at the north and south areas of the site.

\section{TESTING RESULTS}

A brief summary of each trench series is presented below. Each series contained from three to 12 trenches depending on baseline length and location. Excavations averaged seven meters in length and two meters in depth. The locations of the tests are indicated in Figure 2.

\section{Trench Series A}

This series was located in the south-central portion of the survey area and contained 11 excavations $(A T-A 11)$. This area wi11 be impacted by the construction of settling tanks, as well as first and second stage facilities. A single isolated trench (A11) in the extreme southeast corner of the project area was assigned to this series. No cuttural remains were observed in any of the tests.

\section{Trench Series B}

This series was located $150 \mathrm{~m}$ north of Series A. An isolated trench (B12) in the west corner of the survey area was assigned to this series. This area will also be impacted by construction of settling tanks and first and second stage facilities.

A single chert flake was recovered from Trench B6 at one meter below the surface (Fig. 3,a). No other indication of cultural activity, either on the surface or in the profile of Trench B6, was observed.

\section{Trench Series C}

This series was located in the north-central portion of the survey area. This area will be impacted by the construction of the sludge drying beds. The trench series was located to test for the southern 1 imits of $41 \mathrm{BX} 124$. No cultural material was observed in any of the tests.

\section{Trench Series D}

This series was located at the northern limits of the project area on a small east-west ridge with gravel outcrops. Site 41 BX 124 is located at the eastern extreme of the ridge.

A small lithic scatter was observed at Trench D5 (Fig. 2). Artifacts collected included three small cores, one uniface, one tested cobble, and two chert chunks. No subsurface cultural materials were observed. 


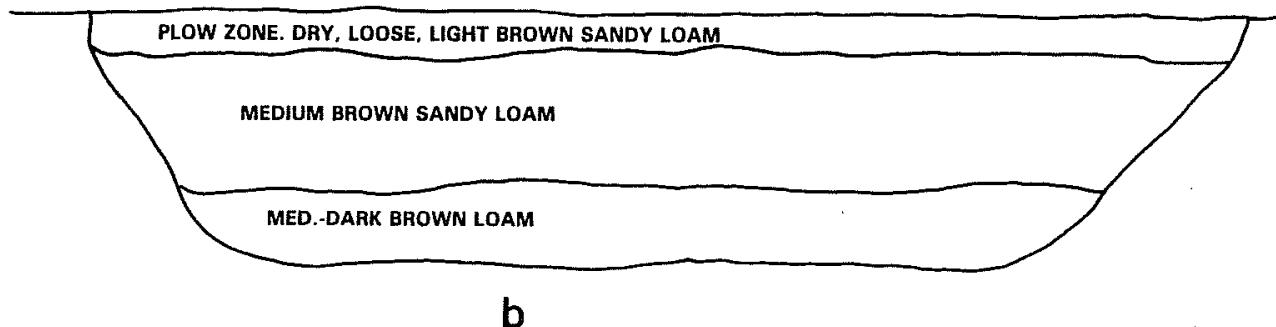

b

PLOW ZONE, LOOSE, YELLOW-BROWN SANDY LOAM

YELLOWISH-BROWN SANDY LOAM, TIGHTLY PACKED

LIGHT BROWN SAND WITH BROWN SANDY LOAM MOTTLING
AND CALICHE NODULES.

PRANGE SAND WITH CALICHE NODULES AND SMALL

CALICHE SHELF

a

Figure 3. Soil Profiles. a, profile of Trench B6; b, profile of Trench F2; c, profile of Trench F5.
RECENT DOMESTIC DEBRIS, DARK BROWN CLAY LOAM

LGHT REDDISH BROWN SILT WITH CALICHE NODULES

C

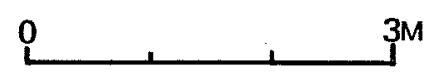


Trench Series E

This series was located in the northeast corner of the survey area at the proposed location of the plant digestors. Because this area has been heavily disturbed by field terracing, trenches were not placed at the usual $100 \mathrm{~m}$ intervals. Two trenches were placed in an undisturbed area at the north end of the series, and one trench was located in an undisturbed area at the south end. No cultural deposits were observed in any of the tests.

\section{Isolated Trenches Fl-5}

These trenches were located in the north-central and northeast limits of the survey area. Trenches F1 and F2 are located within the estimated limits of 41 BX 124. Trench F3 was located in the northeast corner of the proposed sludge drying beds, and Trenches F4 and F5 were placed at the north and south limits of 41 BX 567 .

\section{BX 124}

This site, located on a small ridge overlooking the confluence area, was first recorded by CAR archaeologists in 1977. Additional surveying and testing suggest an occupation date from the Pre-Archaic to the Late Prehistoric period. It was re-examined during the current project, and two backhoe trenches (FI and F2) were excavated within the limits of the site (Fig. 3,b). However, no subsurface cultural deposits were found. Surface artifacts collected included one core, one large uniface, two crude bifaces, and two unifacially retouched chert flakes. A basal fragment from a Bell or Bulverde point was recovered from the surface of a heavily disturbed area $50 \mathrm{~m}$ east of Trench F2.

Although no further testing is recommended at $41 \mathrm{BX} 124$, the earthmoving activities should be monitored during construction of the proposed sludge drying beds.

\section{BX 567}

This site was first recorded during the current project and is located on the west bank of the San Antonio River $700 \mathrm{~m}$ north of its confluence with the Medina River (Fig. 4).

Site 41 BX 567 is a thinly scattered Late Prehistoric site located atop a steep embankment 5-10 m above the river. The site is approximately $200 \mathrm{~m}$ long and 10-15 m wide. Mussel shells, land snail shells, and chert debitage are present throughout the site area. A small sandstone concentration, possibly a hearth, was observed. Subsurface testing included a shovel test $\left(25 \mathrm{~cm}^{2}\right)$ excavated to a depth of $20 \mathrm{~cm}$, and two trenches (F4 and F5) 6-9 $\mathrm{m}$ in length and 1.8-2.0 m deep. Several chert flakes, land snail shells, and mussel shell fragments were recovered from the shovel test. The backhoe trenches (F4 and F5) did not reveal any buried cultural deposits. 
This page has been

redacted because it

contains restricted

information. 
The artifacts collected included one Perdiz point (unfinished), one possible Scallorn point, one Leon Plain ceramic sherd, two unifaces, and three cores. Additional chert debitage, including flakes and chunks, were observed throughout the site area but were not collected.

Site 41 BX 567 appears to be a shallow, deflated site damaged by recent plowing and substantial natural erosion. This site is also subjected to periodic flooding by the San Antonio River. However, it is possible that intact subsurface features are present.

To fully evaluate 41 BX 567 for nomination to the National Register of Historic Places, additional work is necessary. The presence of identifiable point types, ceramics, and a possible hearth further indicate additional work is needed. Detailed site mapping, controlled surface collection, and limited subsurface testing are also recommended.

\section{SUMMARY AND RECOMMENDATIONS}

The project was a five-day surface survey with subsurface testing of 525 acres at the confluence of the Medina and San Antonio Rivers. The property, until recently, a farm owned by Mr. Marvin Ashley, will be the site of the proposed Dos Rios Sewage Treatment Plant. Extensive archaeological survey and testing of the proposed plant location has revealed two archaeological sites, 41 BX 124 and $47 \mathrm{BX} 567$.

Site 41 BX 124 is a multicomponent site located within the Ashley farmstead. The site, first recorded in 1977, has suffered extensive natural erosion along its southern and eastern limits. The site has been further disturbed by the excavation of two large parallel ditches in the vicinity of Trenches F7 and F2. These ditches, 1.5 to $2.0 \mathrm{~m}$ deep, have been used recently as a dump for domestic garbage.

In 1978, CAR archaeologists conducted 1imited subsurface testing at 41 BX 124. No significant cultural deposits were discovered. However, the variety of artifactual materials collected from the site by Mr. Ashley indicated further testing was needed. Recommendations for backhoe trenching in the north and east portions of the site were made.

During the current project, backhoe testing was conducted at $41 \mathrm{BX} 124$. Two backhoe trenches (FI and F2) were excavated in the area recommended by Fox, McGraw, and Valdez (1978). Two additional trenches (D1 and D2) were excavated within the limits of the site. Trench Series $C$ was located to determine the southern limits of $41 \mathrm{BX} 124$. The backhoe testing within $41 \mathrm{BX} 124$ and the immediate area revealed no subsurface cultural deposits.

No additional subsurface testing is recommended. However, it is recommended that an archaeologist selectively monitor any large area or deep constructionrelated excavations at $41 \mathrm{BX} 124$.

Site 41 BX 567, first recorded during the current project, is a Late Prehistoric site on the San Antonio River north of its confluence with the Medina 
River. This site has been disturbed by recent plowing and natural erosion. Two trenches (F4 and $\mathrm{F5}$; Fig. 3,C) and a shovel test were excavated at 41 BX 567. No significant subsurface cultural deposits were observed. The presence of identifiable point types, ceramics, and a possible hearth indicates additional work is needed at the site. This work is essential for a determination of the site's potential for nomination to the National Register of Historic Places.

Although the backhoe testing was extensive in the project area, it was also very selective. The testing program was based on the 1981 preliminary investigations report and additional current engineering plans supplied to the CAR by the joint venture of the consulting engineers. Should these plans for land use be significantly altered, additional testing in the project area would very likely be needed.

\section{REFERENCES CITED}

Anonymous

1981 Preliminary Investigations (A Geological Survey). Malcom Pirnie, Inc., 8118 Broadway, San Antonio, Texas.

Black, S. L. and A. J. McGraw

1982 The Panther Springs Creek Site: Cultural Change and Continuity Within the Upper Salado Drainage, Soùth Central, Texas. Center for Archaeological Research, The University of Texas at San Antonio, Archaeological Survey Report 100 (in preparation).

Blair, W. F.

1950 The Biotic Provinces of Texas. Texas Journal of Science $1(2): 93-116$.

Fawcett, W. B., Jr.

1972 The Prehistory of Bexar County: A Study of Previous Work in South Central Texas. Bulletin, Lower Plains Archaeological Society 2 (for 1971):23-44.

Fox, A. A.

1977 An Archaeological Assessment of the San Antonio 201 Wastewater Treatment Project. Center for Archaeological Research, The University of Texas at San Antonio, Archaeological Survey Report 41. 
Fox, A. A., A. J. McGraw, F. Valdez, Jr.

1978 Archaeological Survey and Testing of the Pipelines and Confluence Site, San Antonio 201 Wastewater Treatment Project. Center for Archaeological Research. The University of Texas at San Antonio, Archaeological Survey Report 66.

Gerstle, A., T. C. Kelly, and C. Assad

1978 The Fort Sam Houston Project: An Archaeological and Historical Assessment. Center for Archaeological Research, The University of Texas at San Antonio, Archaeological Survey Report 40.

Hester, T.R.

1980 Digging Into South Texas Prehistory. Corona Publishing Co., San Antonio.

Hester, T. R., F. A. Bass, Jr., A. A. Fox, T. C. Kelly, M. F. Chadderdon, and $E$. S. Harris

1974 Archaeological Survey of Areas Proposed for Modification in the Salado Creek Watershed, Bexar County, Texas. Center for Archaeological Research. The University of Texas at San Antonio, Archaeological Survey Report 3.

Johnson, E. H.

1931 The Natural Regions of Texas. The University of Texas Bulletin 3173 .

Robinson, R.

n.d. The Study of Biosilica: Reconstructing Paleoenvironments of the Central Coastal Plain of Texas. Center for Archaeological Research, The University of Texas at San Antonio (in preparation).

Taylor, F. B., R. B. Hailey, and D. L. Richmond

1966 Soil Survey of Bexar County, Texas. U.S. Department of Agriculture, in cooperation with the Texas Agricultural Experiment Station.

Woerner, M. C.

1982 A Preliminary Report on an Archaeological Survey of the Proposed Dos Rios Wastewater Treatment Plant Site, South Bexar County, Texas. Report submitted by the Center for Archaeological Research, The University of Texas at San Antonio to Pape-Dawson, Inc., Vickrey and Associates, Inc., and Lockwood, Andrews and Newnam, Inc., a joint venture of consulting engineers. 

